\title{
Middle Jurassic-Early Cretaceous foraminiferal biozonation of the Amran Group, eastern Sana'a Basin, Yemen
}

\author{
Mohammed Al-Wosabi ${ }^{1,2^{*}}$, Mohammed El-Anbaawy ${ }^{3} \&$ Khalid Al-Thour ${ }^{4}$ \\ ${ }^{1}$ Earth and Environmental Sciences Department, Faculty of Science, Sana'a University, P.O. Box 11903, Sana'a, Yemen \\ ${ }^{2}$ Earth Sciences Department, College of Science, Sultan Qaboos University, P.O. Box 36, PC 123, Al-Koud, Muscat, \\ Sultanate of Oman \\ ${ }^{3}$ Geology Department, Faculty of Science, Cairo University, Giza, Egypt \\ ${ }^{4}$ Earth and Environmental Sciences Department, Faculty of Science, Sana'a University, Yemen \\ *corresponding author, e-mail: ma_wosabi@yahoo.com
}

\begin{abstract}
Two sections of strata assigned to the Amran Group at Jabal Salab and Jabal Yam in the eastern Sana'a governorate were sampled and correlated. These sections are part of a carbonate platform that extends from the city of Marib in the east to Naqil Ibn Ghailan, $20 \mathrm{~km}$ east of the city of Sana'a to the west. Palaeontological analysis of samples recovered has resulted in identification of 123 foraminiferal species, which are used to subdivide the sequence of the Amran Group into five biostratigraphic zones, aged between Bathonian (Middle Jurassic) and Berriasian (Early Cretaceous). The proposed biozones are those of Riyadhella rotundata, Kurnubia jurassica, Ammomarginulina sinaica, Alveosepta jaccardi and Pseudocyclammina sulaiyana/Furitilla caspianseis. These biozones were constructed and correlated with the equivalent zones reported from several localities.
\end{abstract}

Key words: Biostratigraphy, Bathonian, Berriasian, Jabal Salab, Jabal Yam

\section{Introduction}

The Amran Group is considered to be one of the most important rock units in Yemen and in the Arabian Peninsula due to its economic potentiality as main hydrocarbon system in the Marib, Al-Jawf and Shabwa basins, as well as its mineralisations (lead, zinc, copper and silver) in the Jabali area (AlGanad et al., 1993). The Amran Group was introduced by Lamare (1923) and Lamare et al. (1930) as the 'Amran Series' to describe carbonate rocks that conformably overlay the Kuhlan Formation near the town of Amran, about $40 \mathrm{~km}$ northwest of Sana'a. Those authors dated it as Dogger-Malm on the basis of fossils on record from the Amran-Kuhlan area. The rank of this rock unit was emended to that of a group by Beydoun $(1964,1966)$, who subdivided it into four formations: Shuqra, Madbi, Sabatain and Naifa (Table 1) and dated the Group as Middle Jurassic (Callovian) to Early Cretaceous (Berriasian) on the basis of fossil content.

The lithostratigraphy of the Amran Group in different areas of Yemen was discussed in detail in several published papers and unpublished works such as those by Botez (1912), Lamare (1923), Lamare et al. (1930), Basse et al. (1954), Beydoun (1964), Geukense (1966), El-Anbaawy (1984), El-Nakhal (1990), Al-Wosabi (1993, 2001, 2005), Simmons \& Al-Thour 
Table 1. Main lithostratigraphic subdivisions of the Amran Group in Yemen and the study area.

\begin{tabular}{|c|c|c|c|c|c|}
\hline Age & & Author & $\begin{array}{l}\text { Lamare } \\
(1930)\end{array}$ & $\begin{array}{c}\text { Beydoun }(1964,1966) \& \text { Beydoun } \\
\text { et al. }(1998)\end{array}$ & El-Anbaawy (1984) \\
\hline Cretaceous & Early & Berriasian & $\begin{array}{l}\text { Transition } \\
\text { Series }\end{array}$ & Naifa Fm & $\begin{array}{l}\text { Jabal Salab/Wadi } \\
\text { Al-Ahjur }\end{array}$ \\
\hline \multirow[t]{5}{*}{ Jurassic } & Late & $\begin{array}{l}\text { Tithonan } \\
\text { Kimmeridgian }\end{array}$ & Amran Series & Madbi Fm/Sabatain Fm & Shuqra Fm \\
\hline & & Oxfordian & & Shuqra Fm & Shuqra Fm \\
\hline & Middle & Callovian & & & \\
\hline & & $\begin{array}{l}\text { Bathonian } \\
\text { Bajocian }\end{array}$ & & Kuhlan Fm & Kuhlan Fm \\
\hline & Early & & Kuhlan Series & & \\
\hline
\end{tabular}

(1994) and Howarth \& Morris (1998). Finally, Beydoun et al. (1998) discussed the position of the group when they introduced the lithostratigraphic subdivisions of Yemen in the international Lexicon of Stratigraphy. They subdivided the Amran Group into four formations: Shuqra, Madbi, Sabatain and Naifa (Table1). Brown et al. (1989) studied this rock unit in the shield area of western Saudi Arabia. The biostratigraphy of the Amran Group has not been discussed by these researchers, with the exception of Al-Wosabi $(1993,2001)$ and Simmons \& Al-Thour (1994).

The Amran Group consists mainly of limestone, marly limestone, shale beds and thick beds of evaporites (salt rocks and gypsum), characterised as the Sabatain Formation in Shabwa "surface outcrops" and Safer "subsurface" areas. The Shuqra Formation consists mainly of limestone with thin shale, siltstone and marl interbeds at several horizons, deposited in a shallow-marine environment. The Madbi and Sabatain formations are lateral equivalents. The former consists of marly clastics which were deposited in an open, shallow-marine en- vironment, while the latter comprises evaporites (gypsum and rock salt) and black shales which were deposited in isolated basins. In the present paper, the subdivision by El-Anbaawy (1984) will be used. He subdivided the Amran Group in northern parts of Yemen, in particular the eastern and western Sana'a basin and neighbouring areas. He introduced the Shuqra and Jabal Salab formations in the eastern parts and Shuqra and Wadi Al-Ahjur formations in the western parts. The Jabal Salab and Wadi Al-Ahjur formations are equivalent with the Naifa Formation of Beydoun (1964) in eastern and southeastern parts of the country (Table 1).The Jabal Salab Formation consists mainly of marl-argillite, bioclastic sandstone and pisolitic limestone, whilst the Wadi Al-Ahjur Formation is characterised by thick beds of marly limestone intercalated with limestone beds.

The present study aims to introduce a foraminiferal biozonation of the Amran Group in the study area and to compare this with equivalent strata in Yemen as well as from other localities.

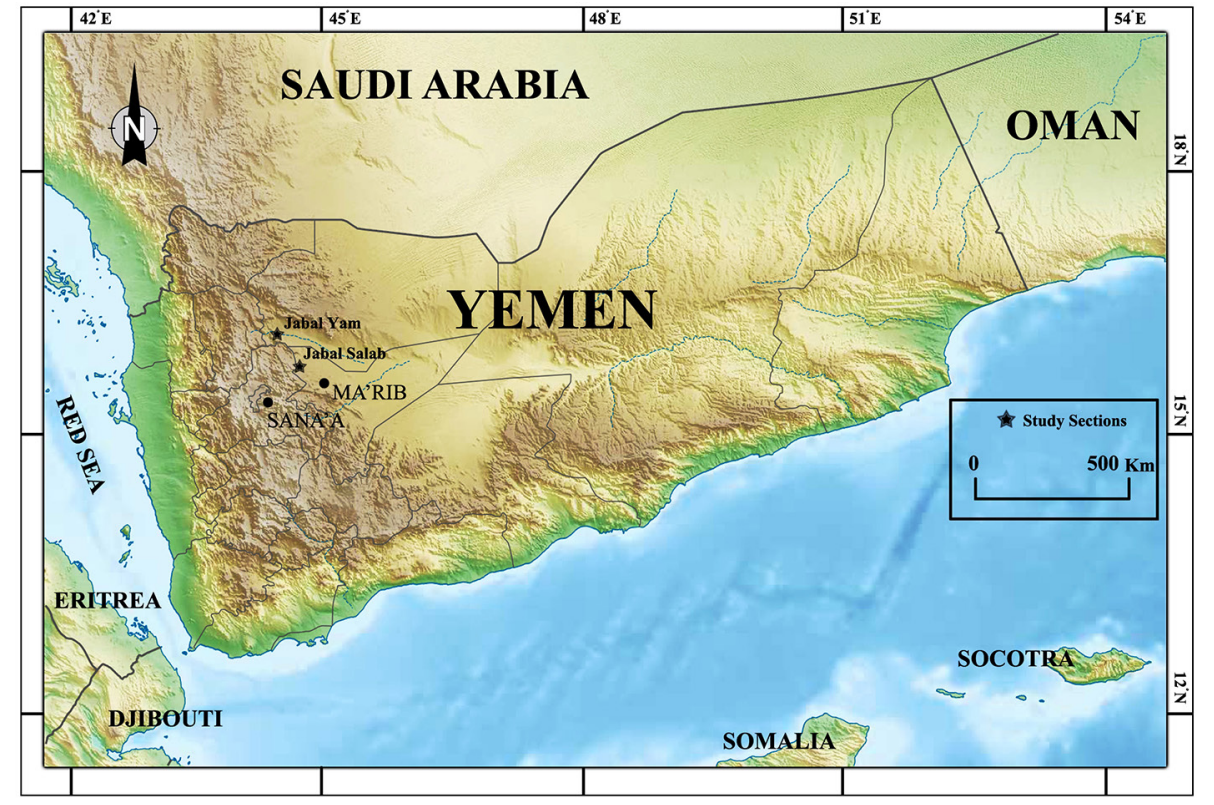

Fig. 1. Location map of the sections studied. 


\section{Study area}

The study area, which is located to the east of the city of Sana'a (Fig. 1), contains Precambrian to Recent rocks including a sedimentary sequence of the Kuhlan Formation, Amran Group, Cretaceous Tawilah Group and Cenozoic volcanics.

The Amran Group overlies the Early to Middle Jurassic Kuhlan Formation (Al-Wosabi \& Wasel, 2011) and is represented by the Shuqra and Jabal Salab formations (Table1). The Madbi and Sabatain formations are missing from the sections studied. The Sabatain Formation is well developed in the neighbouring Al-Ghiras area and in the eastern regions of the country such as the Safer and Shabwah areas, while the Madbi Formation is distributed along the southeasterly regions of the country and in the western areas of Sana'a (Beydoun et al., 1998; El-Nakhal, 1990).

Two sections belonging to the Amran Group at Jabal Salab " $44^{\circ} 45^{\prime} \mathrm{E}, 15^{\circ} 37^{\prime} \mathrm{N}^{\prime}$ and Jabal Yam " $44^{\circ} 33^{\prime} \mathrm{E}, 15^{\circ} 50^{\prime} \mathrm{N}$ " have been measured and described (Figs. 1-3). The Amran Group in these sections consists mainly of thick limestone beds intercalated with marl and marly limestone and occasional dolomitised horizons at different levels (Figs. 2, 3). The Jabal Salab section also contains lead-zinc and silver mineralised horizon. Jabal Yam is accessible along the road from Sana'a to Marib, whilst access to the Jabal Salab section is too difficult through mountainous rough roads by 4-wheel drive vehicles and by walking long distances.

\section{Material and methods}

Eighty-eight samples were collected from these two sections; 40 samples from Jabal Yam and 48 from Jabal Salab, according to changes in lithology, and from the bottom, middle and top of thick beds (i.e., $1 \mathrm{~m}$ or more), with the focus on marl and marly limestone beds (Figs. 2, 3). One hundred and twenty-three foraminiferal species were identified and used for the present study. The biozonation is classified as assemblage zones or taxon range zones. The proposed zonation is correlated with previous works on Jurassic-Early Cretaceous foraminiferal biozones from Yemen, the Middle East, India and Canada.

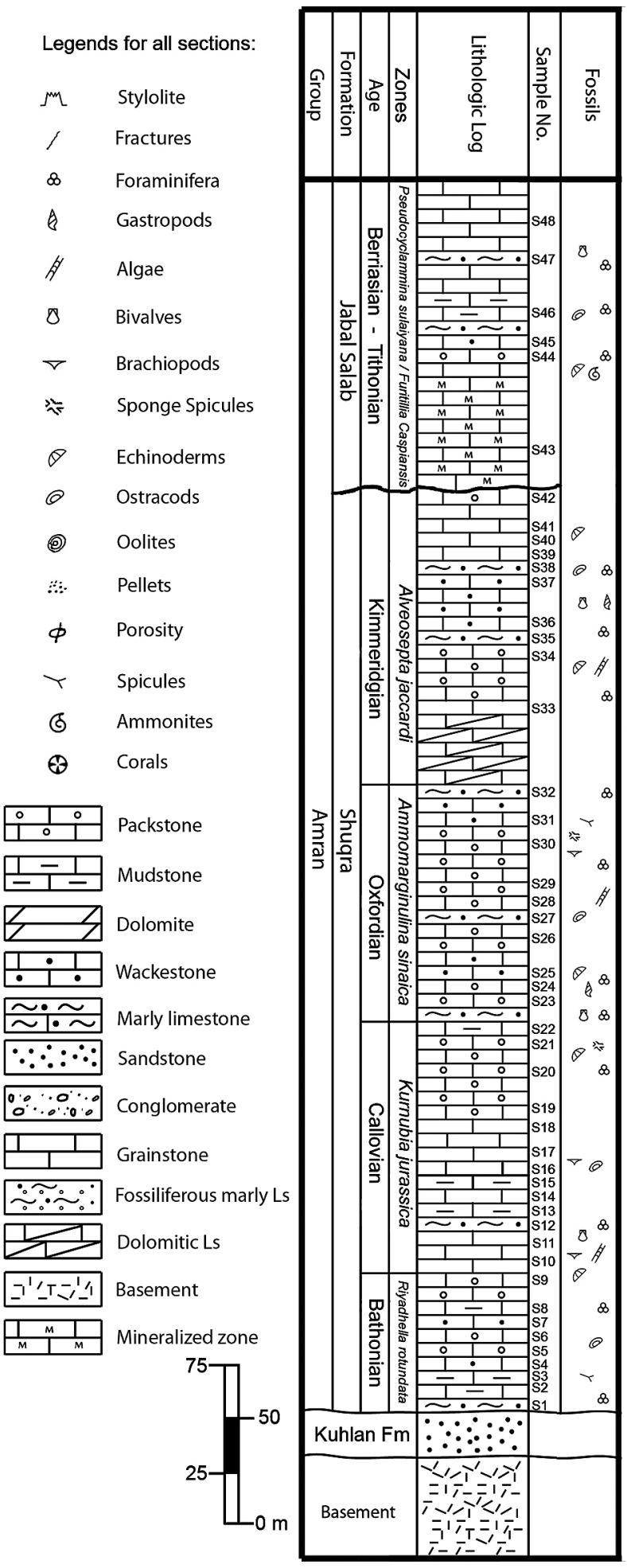

Fig. 2. Lithostratigraphic column of the Jabal Salab section, showing provenance of samples and distribution of the foraminiferal zones proposed. 


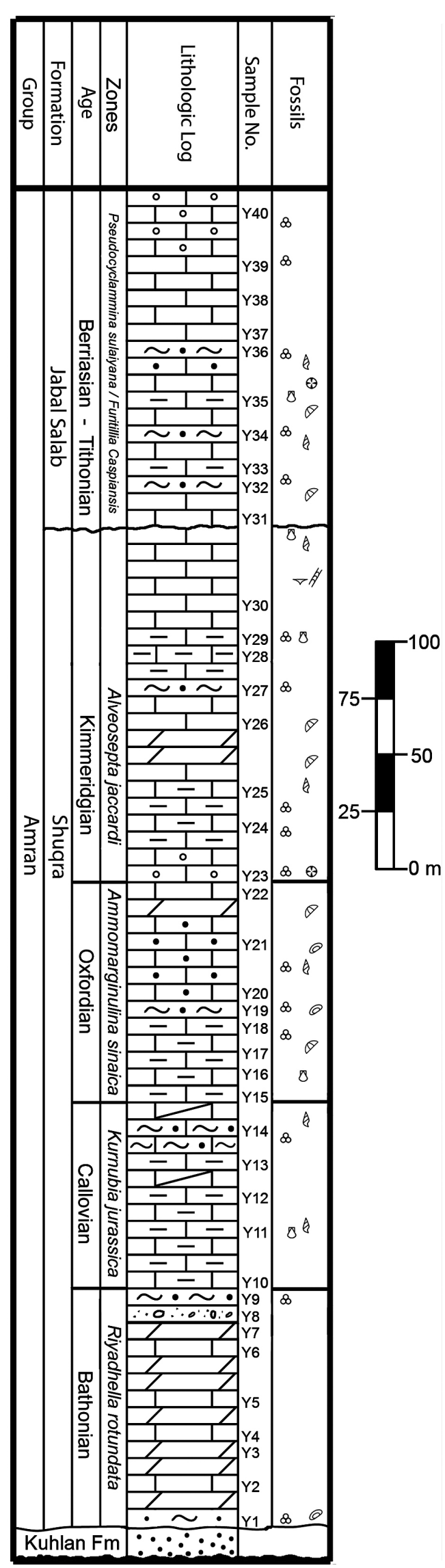

\section{Palaeontology}

The Amran Group is a highly fossiliferous limestone sequence. Invertebrate fossils recorded during fieldwork including bivalves, gastropods, ammonites, belemnites and brachiopods. Micropalaeontological analysis of collected samples from studied sections has led to the identification of 123 foraminiferal species as well as sponge spicules, algal species (e.g., Acicularia sp., Salpingoporella sp. and Revularia sp.), bryozoans and ostracods. The recorded foraminiferal species are listed in Table 2 and their distribution in the Amran Group is shown in Table 3. The recorded foraminiferal species are represented by $67.4 \%$ textulariines, 0.81 miliolines, $25.2 \%$ lagenines, $2.43 \%$ involutines, $2.43 \%$ spirillines and $1.62 \%$ robertines (Table 2 ). The identified foraminiferal assemblage is characterised by a predominance of simple arenaceous and nodosariid species, a rarity of miliolines and the absence of planktonic forms (Table 2). This distribution is consistent with the distribution of foraminifera of the Middle Jurassic in the Middle East (Al-Saad, 2008).

The lower part of the sequence, which constitutes the lower part of the Shuqra Formation (Riyadhella rotundata Zone), contains arenaceous species with simple interiors. This, in addition to the rarity of calcareous forms, indicates that this part of the Shuqra Formation was deposited in a shallow, near-shore environment (Bandy, 1960, 1963; Gordon, 1970; Bhalla \& Abbas, 1978; Grigelis \& Ascoli, 1995; Grigelis \& Norling, 1999). The middle portions of the Shuqra Formation (Kurnubia jurassica and Ammomarginulina sinaica zones) and the upper part (Alveosepta jaccardi Zone) are rich in both arenaceous and nodosariid species which suggests a moderately deep, open marine environment (Norton, 1930; Natland, 1933; Glaessner, 1945; Bielecka \& Pożaryski, 1954; Wall, 1960; Redmond, 1964a, b; Bhalla \& Abbas, 1978; Banner \& Simmons, 1994; Grigelis \& Ascoli, 1995; Grigelis \& Norling, 1999). The uppermost part of the Alveosepta jaccardi Zone (upper part of the Shuqra Formation) and the Pseudocyclammina sulaiyana/Furitillia caspiansis Zone (Jabal Salab Formation), which constitute the upper part of the Amran Group, are characterised by a predominance of simple arenaceous forms and a rarity of calcareous ones which suggests a shallow, near-shore environment.

Fig. 3. Lithostratigraphic column of the Jabal Yam section, showing provenance of samples and distribution of foraminiferal zones proposed. 
Table 2. Foraminiferal species recorded from the sections studied.

\begin{tabular}{|c|c|c|c|}
\hline Suborders & Species & Species & Species \\
\hline \multirow[t]{28}{*}{ Textulariina } & Reophax densa Tappan & A. laevigatus Lozo & T. limbata Kalantari \\
\hline & R. sp.cf. helviticus Haeusler & A. spongiphillus Seibold \& Seibold & T. sp. cf. pullchra Ziegler \\
\hline & R. liasica Franke & A. subaequalis Myatliuk & T. robusta Ziegler \\
\hline & R. metensis Franke & $\begin{array}{l}\text { A. subcretaceous Cushman \& Alex- } \\
\text { ander }\end{array}$ & T. squammata Jones \& Paker \\
\hline & R. sterkii Haeusler & A. suprajurassicum Schwager & Riyadhella regularis Redmond \\
\hline & R. suivicus Franke & A. venustus Loeblich \& Tappan & R. rotundata Redmond \\
\hline & Evolutinella darwini (Dain) & $\begin{array}{l}\text { Ammomarginulina aegyptiaca Osman } \\
\text { \& Hassanein }\end{array}$ & $\begin{array}{l}\text { Paleogaudyina magharaensis Said \& } \\
\text { Barakat }\end{array}$ \\
\hline & E. subevoluta Nikitina \& Myatliak & Am. baryntica Loeblich \& Tappan & Verneuilinoides gracious Dain \\
\hline & $\begin{array}{l}\text { Haplophragmoides sp.cf. arabicus Has- } \\
\text { san \& Others }\end{array}$ & Am. minuta Osman \& Hassanein & V. minuta Said \& Barakat \\
\hline & H. barrowensis Tappan & Am. pullucida Said \& Brand & V. neocomiensis Myatliuk \\
\hline & H. bartensteni Kalantari & Am. sinaica Osman \& Hassanein & V. tryphera Loeblich \& Tappan \\
\hline & H. barthouxi Said \& Barakat & Haplophragmium aequala (Roemer) & V. zerqaensis Basha \\
\hline & H. circularis Said and Barakat & Alveosepta jaccardi (Schrodt) & $\begin{array}{l}\text { Gaudryina vadaszi Cushman \& Glaze- } \\
\text { wski }\end{array}$ \\
\hline & H. hagni Bhalla & Al. Powersi Redmond & Verneuilina anglica Cushman \\
\hline & H. kingakensis Tappan & Everticyclammina contorta Redmond & Pfenderina gracilis Redmond \\
\hline & H. tryssa Loeblich and Tappan & E. eccentrica Redmond & P. inflata Redmond \\
\hline & Nautiloculina oolithica Mohler & Bramkampella arabica Redmond & Steinekella steinekei Redmond \\
\hline & Ammobaculites alaskensis Tappan & Feuritillia caspiansis Kalantari & Kurnubia jurassica (Henson) \\
\hline & A. alexanderi Cushman & $\begin{array}{l}\text { Pseudocyclammina rogalia Cushman \& } \\
\text { Glazewski }\end{array}$ & K. morissi Redmond \\
\hline & A. barrowensis Tappan & P. sulaiyana Redmond & K. palastiniensis Henson \\
\hline & A. braunsteini Cushman \& Applin & Bimonilina variana Eicher & K. variabilis Redmond \\
\hline & A. cobbani Loeblich \& Tappan & Plectinella aegyptiaca Said \& Barakat & Praekurnubia crusi Redmond \\
\hline & A. coprolithiformis (Schwager) & Textulariopsis jurassica (Gumbel) & Marssonella oxycona (Reuss) \\
\hline & A. crespinae Bhalla & $\begin{array}{l}\text { Trochammina bartensteni Said \& } \\
\text { Barakat }\end{array}$ & Pseudomarsonella bipartita Redmond \\
\hline & A. fontinensis (Tappan) & T. concava Seibold \& Seibold & P. reflexa Redmond \\
\hline & A. hofkeri Bhalla & T. conningensis Tappan & P. maxima Redmond \\
\hline & A. indicus Bhalla & T. gryci Tappan & P. plicata Redmond \\
\hline & $\begin{array}{l}\text { A. irregulariformis Bartenstein \& } \\
\text { Brand }\end{array}$ & T. inflata (Montagu) & \\
\hline Involutinina & Trocholina conica (Schlumberger) & T. delicatissima Kalantari & T. nodulsa Seibold \& Seibold \\
\hline Spirillinina & $\begin{array}{l}\text { Spirillina amphilicata Loeblich \& } \\
\text { Tappan }\end{array}$ & S. infima Strickland & S. polygyrata Gumbel \\
\hline Miliolina & Massilina rediclaffensis Gordon & & \\
\hline \multirow[t]{11}{*}{ Lagenina } & Dentalina plebeia Terquem & Saracenaria cornucopiae (Schwager) & $\begin{array}{l}\text { Vaginulina composa Loeblich \& } \\
\text { Tappan }\end{array}$ \\
\hline & Nodosaria fontinensis Terquem & S. triangularis (D'Orbigny) & $\begin{array}{l}\text { Eoguttulina amygdalina Loeblich \& } \\
\text { Tappan }\end{array}$ \\
\hline & N. kuhni Franke & $\begin{array}{l}\text { Astacolus aphrastus Loeblich \& } \\
\text { Tappan }\end{array}$ & E. bilocularis (Terquem) \\
\hline & N. nitidana Brand & A. crepidula (Fichtel \& Moll) & $\begin{array}{l}\text { E .inovroclaviensis (Bielecka \& Po- } \\
\text { zaryski) }\end{array}$ \\
\hline & $\begin{array}{l}\text { Frondicularia dentaliniformis (Ter- } \\
\text { quem) }\end{array}$ & A. pediacus Tappan & E. liasica (Strickland) \\
\hline & Lenticulin audax Loeblich \& Tappan & $\begin{array}{l}\text { Vaginulinopsis enodis Loeblich \& } \\
\text { Tappan }\end{array}$ & E. polygona (Tarquem) \\
\hline & L. muensteri (Roemer) & V. epicharis Loeblich \& Tappan & E. triloba (Terquem) \\
\hline & L. quenstedti (Gumbel) & V. misrensis Said \& Barakat & Globulina lacrima (Reuss) \\
\hline & L. subalata (Reuss) & Planularia anceps (Terquem) & G. sp. cf. prisca Reuss \\
\hline & L. varians (Bornemann) & P. beierana (Gumbel) & Guttulina pera Lalicker \\
\hline & & & G. physalia Loeblich and Tappan \\
\hline Robertinina & Epistomina caracolla (Roemer) & Epistomina mosquensis Uhlig & \\
\hline
\end{tabular}




\section{Age and biostratigraphy}

The biostratigraphy of the Amran Group in Yemen was studied by Al-Wosabi (1993), who used the foraminiferal species that were recorded from the Jabali area, east of Sana'a, and by Simmons \& AlThour (1994), who constructed a biozonal scheme on the basis of foraminiferal and algal contents from the western areas of Sana'a region. The succession of the Amran Group in the sections studied includes the Shuqra and Jabal Salab formations. The total count of identified foraminiferal species from the two studied sections reaches 123 . Ninety-eight species are recorded from Jabal Yam and one hundred and three from Jabal Salab with some duplication. The stratigraphical range of these species was restricted between Bathonian (Middle Jurassic) and Berriasian (Early Cretaceous) (Table 3). Biostratigraphic subdivision of the Amran Group based on foraminiferal data does not provide high-resolution zones which is a result of the slower rate of evolution of Jurassic foraminifera, which is substantiated by rather long geological ranges for most of the species. However, within a basin, local associations and their distribution provide a fair basis for biostratigraphic classification. Few of the recorded species displayed a wide range; two examples are Reophax suevica Franke "Rhaetian-Tithonian" and Lenticulina muensteri (Roemer) "Rhaetian-Hauterivian". Several of the recorded species were considered index species ranging in age from Late Jurassic to earliest Cretaceous, particularly in Middle East countries, including Bramkampella arabica Redmond and Pseudocyclammina sulaiyana Redmond. On the other hand, there are many species which recorded as an index fossils of the Middle-Late Jurassic such as Kurnubia jurassica Henson, K. palastinensis Henson, K. morissi Redmond, K. variabilis Redmond, Pfenderina gracilis Redmond, P. inflata Redmond, Stienekella stienekei Redmond, Pseudomarssonella bipartita Redmond, P. maxima Redmond, $P$. plicata Redmond, P. reflexa Redmond, Riyadhella regularis Redmond, $R$. rotundata Redmond, Reophax helveticus Häusler, Haplophragmoides arabicus Hassan, Hassanien \& Abd El-Shafy, H. barthoxi Said \& Barakat, H. circularis Said \& Barakat, Ammomarginulina pullucida Said \& Barakat, Plectinella aegyptiaca (Said \& Barakat), Vaginulina misrensis Said \& Barakat, Ammobaculites braunsteini Cushman and Applin, A. cobbani Loeblich \& Tappan, A. venustus Loeblich \& Tappan, Ammomarginulina baryntica Loeblich \& Tappan, Astacolus aphrastus Loeblich \& Tappan, Vaginulina composa Loeblich and Tappan, Eoguttulina amygdalina Loeblich and Tappan, Alveosepta jaccardi (Schrodt), A. powersi Redmond, Ammomarginulina aegyptiaca Said and Barakat, A. minuta Osman \& Hassanein, A. sinai- ca Osman \& Marzouk, Textulariopsis jurassica (Gümbel) and many other species.

Based on the vertical distribution of the recorded foraminifera, i.e., first appearance, last disappearance of a certain species and abundance of some species in the sequence, five biozones were recognised (Table 3). In ascending order, these zones are: Riyadhella rotundata Zone, Kurnubia jurassica Zone, Ammomarginulina sinaica Zone, Alveosepta jaccardi Zone and Pseudocyclammina sulaiyana/Furtillia caspiansis Zone. The proposed zones find confirmation in earlier papers by different researchers such as Kalantari (1969), Souaya (1976), Hassan et al. (1978), Kalia \& Chowdhury (1983), Abd El-Shafy (1984),Williams et al. (1990), Al-Wosabi (1993, 2001, 2005), Simmons \& Al-Thour (1994), Kuznetsova et al. (1996), Hewaidy \& Al-Saad (2000), Al-Saad (2008) and Sarfi \& Yazdi-Moghadam (2016).

\subsection{Riyadhella rotundata Zone}

This zone was introduced by Kalia \& Chowdhury (1983) in the Bathonian of India. The base of the Riyadhella rotundata Zone equates with the first appearance of Riyadhella rotundata Redmond, while the top is marked by the disappearance of the foraminiferal species of the Riyadhella rotundata Zone and the first appearance of Kurnubia palastinensis Henson. Conspicuous species in this zone are Astacolus pediacus Tappan, Nodosaria fontinensis Terquem, N. kuhni Franke, Dentalina plebae Terquem, Trochammina bartensteini Said \& Barakat, T. robusta Ziegler, Ammobaculites braunsteini Cushman \& Applin, Trocholina delicatissima Kalantari, Riyadhella regularis, Haplophragmoides barthoxi, $H$. barrowensis Tappan, Reophax liasica Terquem, R. suevica Franke, Paleogaudryina magharaensis Said \& Barakat, Pfenderina inflata Redmond, Verneuilinoides zerqaensis Basha, V. minuta Said \& Barakat, Eoguttulina bilocularis (Terquem), Lenticulina varians Bornemann, Frondicularia dentaliniformis (Terquem), Ammobaculites venustus Loeblich and Tappan, A. suprajurassicum (Schwager), A. fontinensis (Terquem), A. barrowensis Tappan, A. alaskensis Tappan, A. cobbani, Planularia beierana (Gümbel) and Pseudomarssonella reflexa Redmond. This zone represents the lower part of the Shuqra Formation in the sections studied and is of Bathonian age (Table 3).

\subsection{Kurnubia jurassica Zone}

The base of this zone equates with the first appearance of Kurnubia species, which is considered 
an index species of the Middle-Upper Jurassic in the Middle East. The upper limit of this zone is taken at the disappearance of Kurnubia jurassica and the first appearance of Ammomarginulina sinaica Osman and Hassanein. This zone is rich in Kurnubia palastinensis Henson, K. jurassica, K. variabilis Redmond, Planularia anceps (Terquem), Astacolus crepidula (Fichtel \& Mole), Guttulina pera Lalicker, Vaginulinopsis misrensis Said \& Barakat, Lenticulina subalata Reuss, Nodosaria nitidana Brand, Ammomarginulina aegyptiaca Said and Barakat, A. minuta, T. inflata (Montagu), Trochammina sp. cf. pullchra Ziegler, Trocholina conica Schlumberger, Plectinella aegyptiaca (Said \&
Barakat), Haplophragmoides sp. cf. arabicus Hassan, Hassanein and Abd El-Shafy, H. circularis, Pfenderina gracilis Redmond, Praekurnubia crusi Redmond, Pseudomarssonella bipartita, P. maxima, P. plicata Redmond and Reophax densa Tappan.

The Kurnubia jurassica Zone can be correlated with Trocholina spp / Kurnubia palestiniens of Simmons \& Al- Thour (1994), which were identified in the upper Callovian of the Sana'a region and with the Kurnubia variabilis Zone of Al-Wosabi (1993). In addition, this zone is equivalent to the Kurnubia jurassica Zone (Hassan et al., 1978; Abd El-Shafy, 1984), the Kurnubia palastinensis Zone (El-Badry et

Table 3. Foraminiferal biozonation of the Amran Group in the study area.

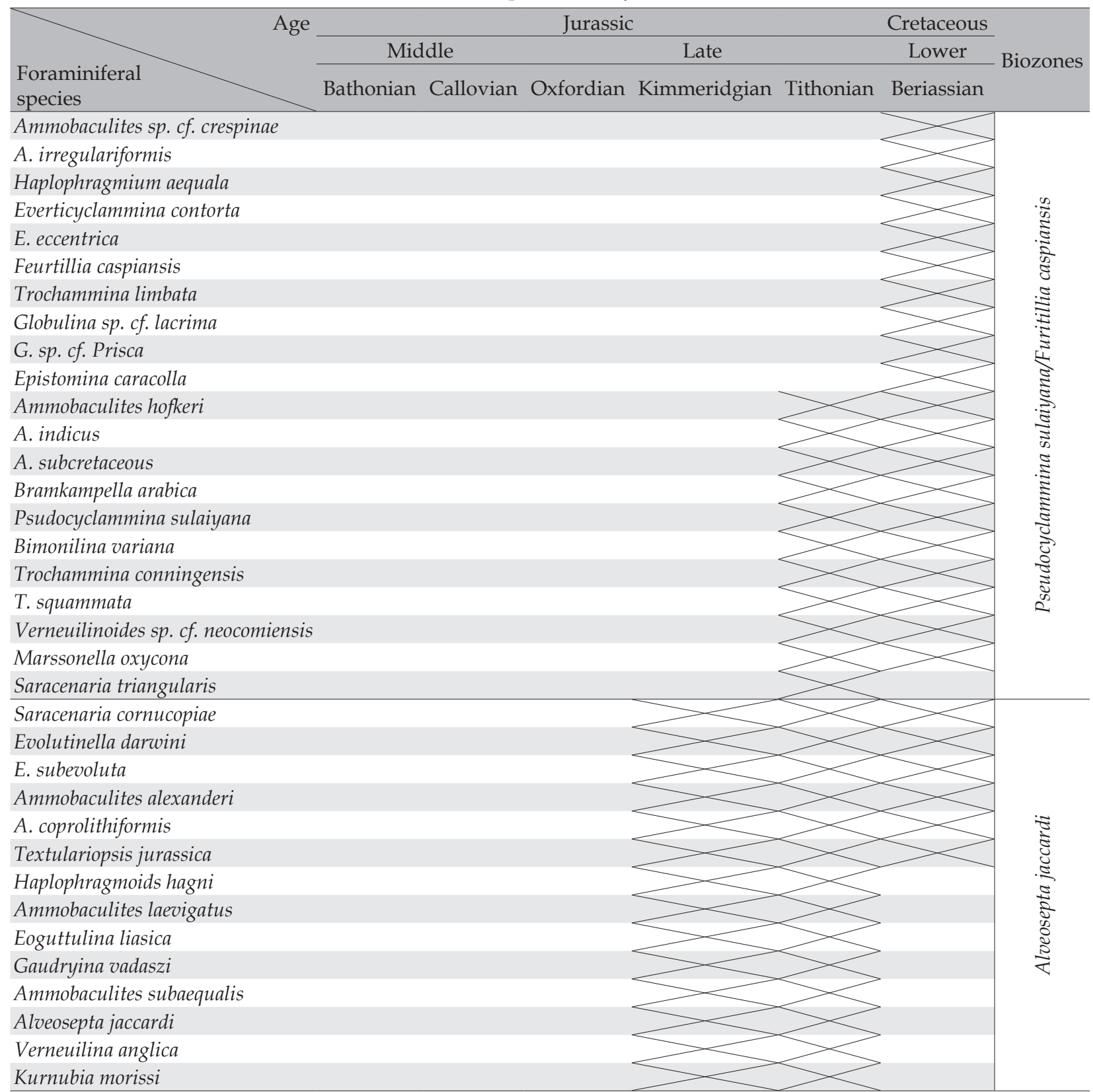




\begin{tabular}{|c|c|c|c|c|c|}
\hline \multirow[b]{3}{*}{$\begin{array}{l}\text { Foraminiferal } \\
\text { species }\end{array}$} & \multirow[t]{3}{*}{ Age } & \multicolumn{2}{|r|}{ Jurassic } & Cretaceous & \multirow{3}{*}{ - Biozones } \\
\hline & & Middle & Late & Lower & \\
\hline & & Bathonian Callovian & Oxfordian Kimmeridgian & Tithonian Beriassian & \\
\hline
\end{tabular}

Lenticulina muensteri

Eoguttulina inovroclaviensis

E. polygona

Spirillina infima

Verneuilinoides tryphera

Spirillina amphilicata

S. polygyrata

Eoguttulina amygdalina

E. triloba

Guttulina physalia

Nautiloculina oolithica

Ammomarginulina pullucida

Pseudocyclammina rogalia

Epistomina mosquensis

Masselina rediclaffensis

Lenticulina audax

L. quenstedti

Astacolus aphrastus

Vaginulinopsis enodis

$V$. epicharis

Ammomarginulina sinaica

Vaginulina composa

Reophax sp. cf. helviticus

R. metensis

R. sterkii

Haplophragmoides bartensteni

H. kingakensis

H. tryssa

Ammobaculites spongiphillus

Ammomarginulina baryntica

Alveosepta powersi

Trochammina concava

T. gryci

Verneuilinoides gracious

Steinekella steinekei

Trocholina nodulsa

Trochammina inflata

Reophax densa

Ammomarginulina aegyptiaca

Am. minuta

Trochammina sp. cf. pullchra

Trocholina conica

Nodosaria nitidana

Lenticulina subalata

Vaginolinopsis misrensis

Guttulina pera

Plectinella aegyptiaca

Haplophragmoides sp. cf. arabicus

H. circularis

Pfenderina gracilis

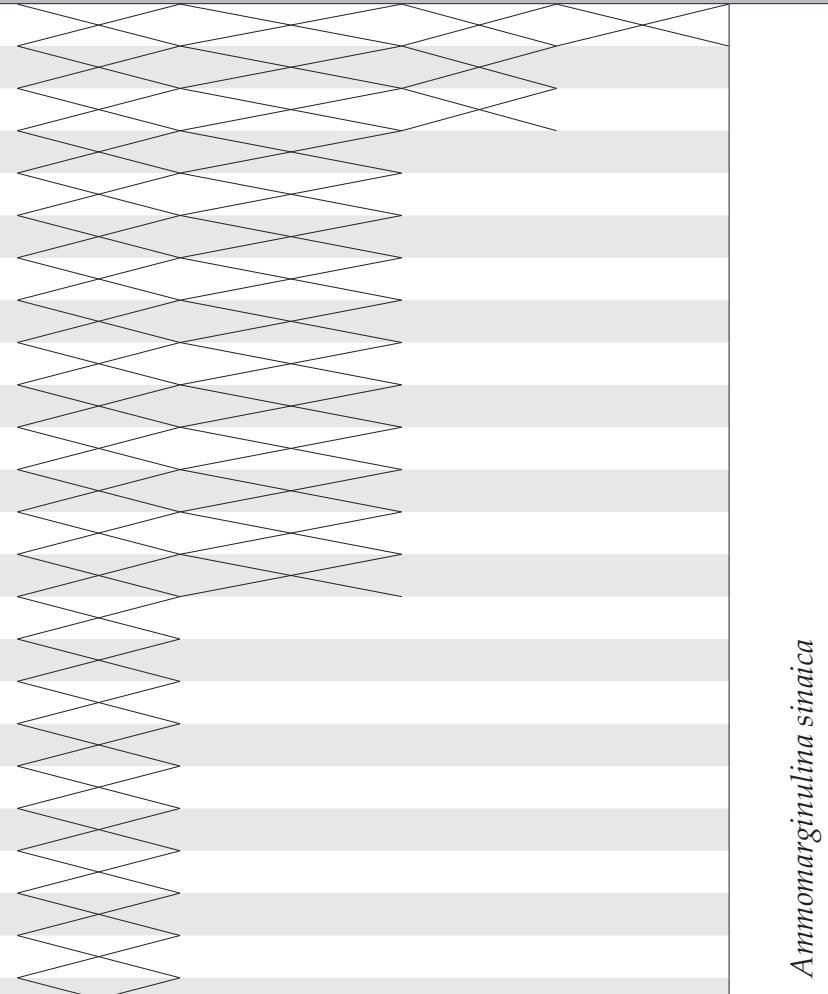




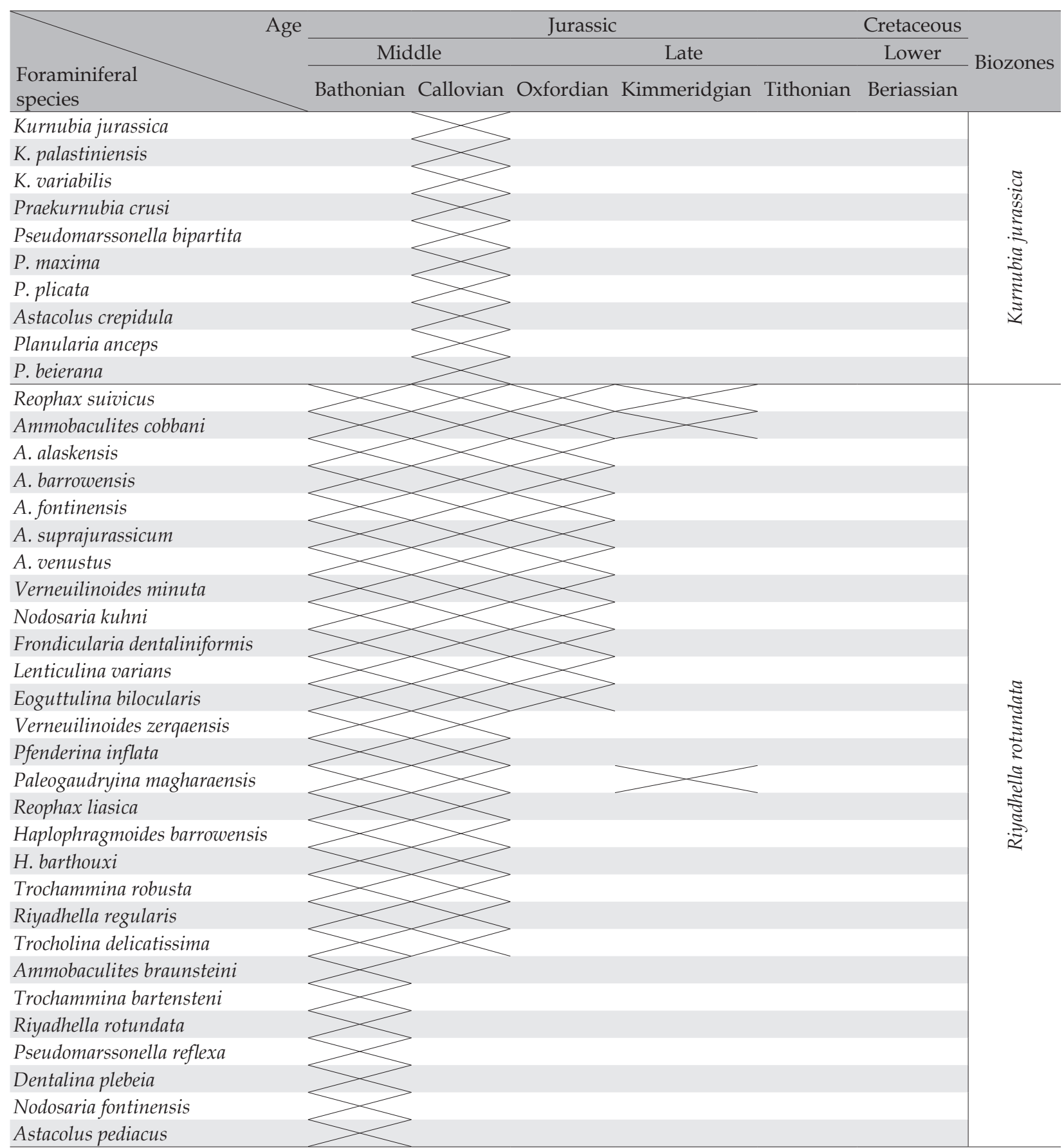

al., 1981) and the Kurnubia gigantea Zone (Abd ElShafy \& Ibrahim, 1987) in Egypt. This zone represents the beginning of the middle part of the Shuqra Formation and is of Callovian age (Table 3).

\subsection{Ammomarginulina sinaica Zone}

The present zone was established by Hassan et al. (1978) in Egypt and later also documented by El-Badry et al. (1981) and Abd El-Shafy (1984). The
Ammomarginulina sinaica Zone is of Oxfordian age in the study area. It starts with the first appearance of Ammomarginulin asinaica. This is the richest zone as far as foraminiferal content is concerned in the sections studied. Some species, which appeared in the underlying zones, are still present in this zone together with newly appearing forms. The foraminiferal species which characterise this zone include Trocholina nodulsa Seibold \& Seibold, Steinekella steinekei Redmond, Verneuilinoides gracious Dain, $V$. tryphera Loeblich \& Tappan, Trochammina concava 


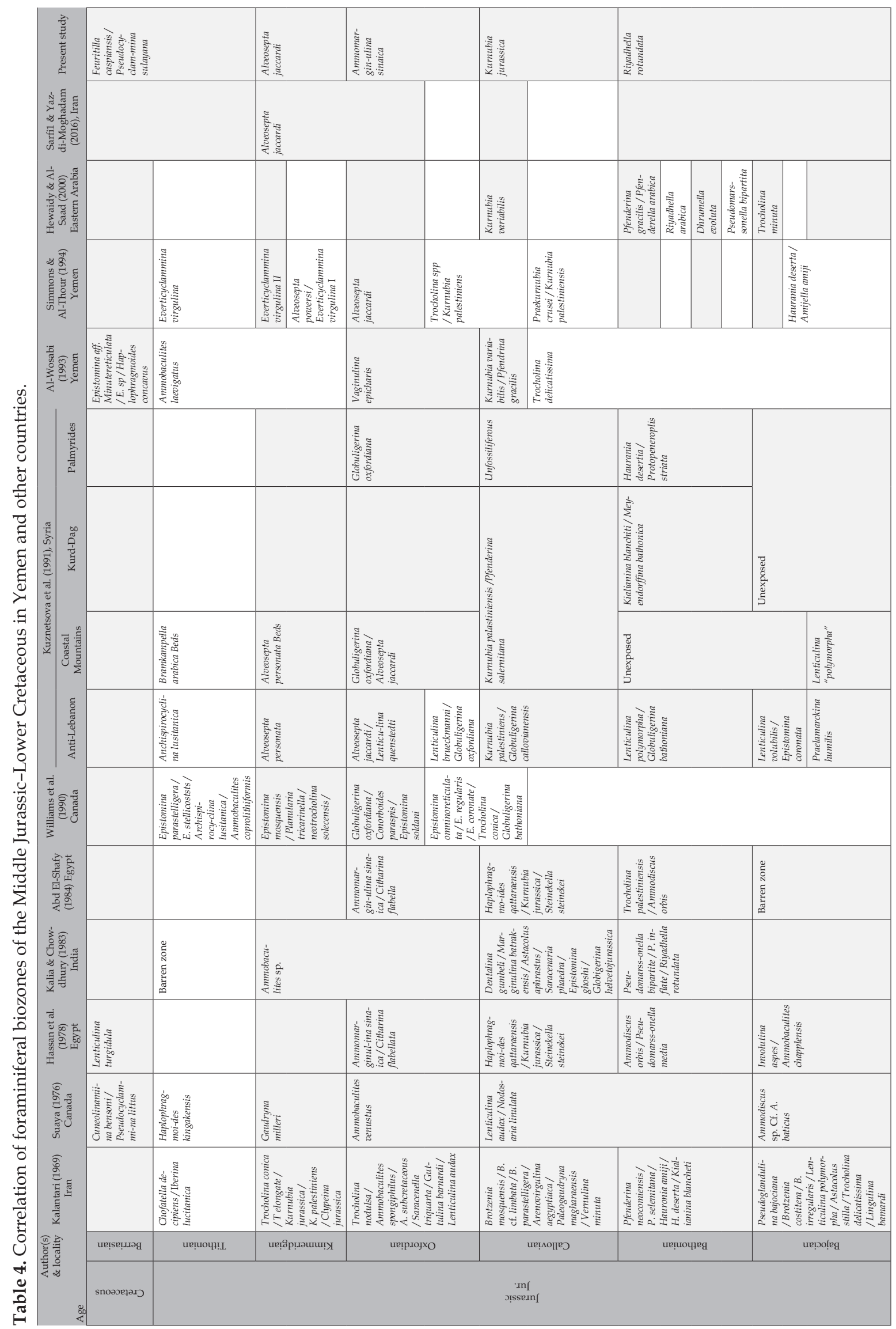


Seibold \& Seibold, T. gryci Tappan, Ammomarginulina baryntica Loeblich \& Tappan, A. pullucida Said \& Barakat, Ammobaculites spongiphilus Seibold \& Seibold, Haplophragmoides tryssa Loeblich \& Tappan, H. kingakensis Tappan, H. bartensteini Kalantari, Reophax sterkeii Häusler, R. metensis Franke, $R$. sp. cf. helviticus Häusler, Pseudocyclammina rogalai Cushman \& Glazewski, Nautiloculina oolithica Mohler, Eoguttulina inovroclaviensis (Bielicka \& Pożaryski), E. polygona (Terquem), Lenticulina muensteri (Roemer), L. audax Loeblich \& Tappan, L. quenstedti (Gümbel), Spirillina amphilicata Loeblich \& Tappan, S. polygyrata Gümbel, S. infima (Strickland), Massilina rediclaffensis Gordon, Astacolus aphrastus Loeblich \& Tappan, Vaginulinopsis enodis Loeblich \& Tappan and V. epicharis Loeblich \& Tappan.

This zone can be correlated in part with the Trocholina spp./Kurnubia palastinensis Zone and with the Alveosepta jaccardi Zone of Simmons \& Al-Thour (1994) and Vaginulinopsis epicharis Zone of Al-Wosabi (1993). This zone is of Oxfordian age in the study area and characterises the middle part of the Shuqra Formation (Table 3).

\subsection{Alveosepta jaccardi Zone}

This zone is equivalent to the Everticyclammina virgulina I, Alveosepta powersi and Everticyclammina II Zone of Simmons and Al-Thour (1994) and to the Ammobaculites laevigatus Zone of Al-Wosabi (1993).

The Alveosepta jaccardi Zone was used previously by Ascoli $(1981,1988)$ and Williams et al. (1990) to characterise the Kimmeridgian of Canada and Sarfi \& Yazdi-Moghadam (2016) as a late Oxfordian-early Kimmeridgian zone in northwest Iran.

This zone begins with the disappearance of Ammomarginulia sinaica and the first appearance of Alveosepta jaccardi. The upper limit of this zone equates with the first appearance of Pseudocyclammina sulaiyana Redmond and the foraminiferal species that belong to the youngest zone of the Amran Group. Conspicuous foraminiferal species within this zone are Kurnubia morissi, Verneuilina anglica Cushman, Alveosepta jaccardi and Ammobaculites subaequalis Myatliuk, A. laevigatus Lozo, A. alexanderi Cushman, A. coprolithiformis Schwager, Gaudryina vadaszi Cushman \& Glazewski, Haplophargmoides hagni Bhalla, Evolutinella darwini Dain, E. subevoluta Nikitina \& Myatliuk, Textulariopsis jurassica (Gümbel), Eoguttulina liasica (Strickland) and Saracenaria cornucopiae (Schwager). Several species represented in this zone continue into the overlying Pseudocyclammina sulaiyana/Feurtillia caspiansis Zone. This zone is of Kimmeridgian age and represents the upper part of Shuqra Formation (Table 3).

\subsection{Pseudocyclammina sulaiyana/Feurtillia caspiansis Zone}

This zone includes many foraminiferal species that are held typical of the uppermost Jurassic and lowermost Cretaceous such as Pseudocyclammina sulaiyana Redmond, Bramkampella arabica Redmond, Everticyclammina contorta Redmond, E. eccentrica Redmond, Trochammina limbata Kalantari, Feurtillia caspiansis Kalantari, Haplophragmium aequala (Roemer), Ammobaculites alexanderi Cushman, A. indicus Bhalla, A. hofkeri Bhalla, A. sp. cf. crespinae Bhalla, Epistomina caracolla (Roemer), Globulina lacrima (Reuss), Evolutinella subevoluta Nikitina \& Myatliuk and E. darwini Dain. The base of this zone equates with the appearance of Pseudocyclammina sulaiyana and its top is defined by the disappearance of the foraminiferal species of the Amran Group. The age of this zone is latest Jurassic (Tithonian)-earliest Cretaceous (Berriasian) (Table 3).

\section{Correlations}

The foraminiferal biozonation of the Middle Jurassic-Lower Cretaceous in the study area is correlated with previously proposed foraminiferal biozones by different workers locally in Yemen and regionally in different regions (Table 4). In Yemen, this biozonation often corresponds with that of Al-Wosabi (1993) and Simmons and Al-Thour (1994) which have been based on benthic foraminifera and algal contents. Regional correlation is based on previously published papers for different regions such as Iran (Kalantari, 1969; Sarfi \& Yazdi-Moghadam, 2016), Canada (Souaya, 1976; Williams et al., 1990), Egypt (Hassan et al., 1978; Abd El-Shafy, 1984), India (Kalia \& Chowdhury, 1983), Syria (Kuznetsova et al., 1996) and eastern Saudi Arabia (Hewaidy \& Al-Saad, 2000).

\section{Conclusions}

The foraminiferal biozonation of the Amran Group in the study area is introduced on the basis of 123 foraminiferal species from the samples collected. These biozones include four taxon range zones (Riyadhella rotundata, Kurnubia jurassica, Ammomarginulin asinaica and Alveosepta jaccardi zones) as well as a single assemblage zone, Pseudocyclam- 
mina sulaiyana/Furitilla caspiansis Zone. These zones are restricted in age between the Bathonian and Berriasian. This biozones are correlated with equivalent zones in Yemen and some Tethyan regions.

\section{Acknowledgements}

The authors are deeply indebted to Prof. Dr. M.G. Barakat (Department of Geology, Cairo University) for checking fossil identifications. One of us (M. Al-Wosabi) would like to record his gratitude to the late Prof. Dr. Hamed El-Nakhal (formerly Environmental and Earth Science Department, Islamic University, Gaza, Palestine) for fruitful discussions. We also thank two anonymous reviewers for critical revision of an earlier typescript.

\section{References}

Abd El-Shafy, E., 1984. Stratigraphy of subsurface Jurassic in Qattara Depression and its relation with similar sections in Egypt and in the Tethyan regions. In: I. Klerkx \& T. Ichot (Eds): African Geology, Tervuren, 247-259.

Abd El-Shafy, E. \& Ibrahim, N., 1987. Litho-bio-chronoeco-Stratigraphy and regional correlation of Bu-Hammad, Jurassic, Egypt. Bulletin of Faculty of Science, Zagazig University 9, 395-425.

Al-Ganad, I., Lang., P., Lescuyer, J., Ramboz, C. \& Touray, J., 1993. Jabali, a Zn-Pb-(Ag) carbonate-hosted deposit associated with Late Jurassic rifting in Yemen. Mineralium Deposita 29, 44-56.

Al-Saad, H., 2008. Stratigraphic distribution of the Middle Jurassic foraminifera in the Middle East. Revue de Paléobiologie 27, 1-13.

Al-Wosabi, M.A., 1993. Biostratigraphy of the Amran Formation (Middle- Late Jurassic) in the Republic of Yemen. Thesis of Sana'a University, 129 pp.

Al-Wosabi, M.A., 2001. Stratigraphical and sedimentological studies on the Jurassic Amran

Sequence East Sana'a District, Yemen Republic. Thesis of Sana'a University, 278pp.

Al-Wosabi, M.A., 2005. Stratigraphy of the Middle-Late Jurassic foraminifera in the western

and northwestern regions of Sana'a Basin, Republic of Yemen, Faculty of Science Bulletin, Sana'a University 18, 71-114.

Al-Wosabi, M.A. \& Wasel, S., 2011. Lithostratigraphic subdivision of the Kuhlan Formation in Yemen. Arabian Journal of Geosciences 4, 1323-1335.

Ascoli, P., 1981. Foraminiferal-Ostracode late Jurassic Biozonation of the Scotian shelf. Geological survey of Canada, Open file 753, $32 \mathrm{pp}$.

Ascoli, P., 1988. Mesozoic-Cenozoic foraminiferal, ostracod and calpionellid zonation of the north Atlantic margin of North America: Georges Bank - Scotian basins and northeastern Grand Bank (Jeanne d'Arc, Carson and Flemish pass basin). Biostratigraphic cor- relation of 51 wells. Geological Survey of Canada, open file 1971, $41 \mathrm{pp}$.

Bandy, O.L., 1960. General correlations of foraminiferal structure with environment. International Geological Congress, $21^{\text {st }}$ Section. Copenhagen, Rept. Session, 7-19.

Bandy, O.L., 1963. Dominant paralic foraminifera of southern California and the Gulf of California. Cushman Foundation for Foraminiferal Research Center 14, 127-134.

Banner, F.T. \& Simmons, M.D., 1994. Calcareous algae and foraminifera as water depth indicators: an example from the Early Cretaceous carbonates of northeast Arabia. [In:] M. Simmons (Ed.): Micropaleontology and hydrocarbon exploration in the Middle East. British Micropaleontological Society Publication Series, Chapman and Hall, London, 243-252.

Basse, E., Karrenberg, H., Lehman, J., Alloiteau, J. \& Lefrance, L., 1954. Fossils du Jurassique superieur et des Gres de la Region de Sana (Yemen). Bulletin de la Societe Geologique de France 6, 47-9, 655-688.

Beydoun, Z.R., 1964. The Stratigraphy and Structure of the Eastern Aden. Overseas Geology and Mineral Resources Supplement Series 5, 107 pp.

Beydoun, Z.R., 1966. Geology of the Arabian Peninsula, Eastern Aden Protectorate and part of Dhufar. United States Geological Survey Professional Paper 560-H, 49 pp.

Beydoun, Z.R., As-Saruri, M.L., El-Nakhal, H., Al-Ganad, I.N., Baraba, R.S., Nani, A.O. \& Al-Aawah, M.H., 1998. International lexicon of stratigraphy, Republic of Yemen: v. III, Asia, fascicule, 10b2. IUGS Publication 34, 245 pp. Doi: 10.1017/S001675689922290X.

Bhalla, S.N. \& Abbas, S.M., 1978. Jurassic foraminifera from Kutch, India. Micropaleontology 24, 160-209.

Bielecka, W. \& Pożaryski, W., 1954. Micropaleontological stratigraphy of the Upper Malm in Central Poland: Prace Instytutu Geologicznego 12, 143-206.

Botez, G., 1912. Rapport d elinitif sur les etudes geohydrologiques faites en Yemmen (Arabie). Bucarest Universala, 72.

Brown, G.F., Schmidt, D.L. \& Huffman, Jr.A.C., 1989. Geology of the Arabian Peninsula, Shield area of Western Saudi Arabia. United States Geological Survey Professional Paper 560A, 188 pp.

El-Anbaawy, M., 1984. Contribution to the lithostratigraphic subdivisions of the Amran sequence in the Yemen Arab Republic. Bulletin of Faculty of Science, Sana'a University 4, 65-84.

El-Badry, O., Hassanien, A.M. \& Abd El-Shafy, E., 1981. Biostratigraphy of the Jurassic rocks, Khashm El-Galala Area, Gulf of Suez, Egypt. Bulletin of Faculty of Science, Zagazig University 3, 79-101.

El-Nakhal, H.A., 1990. Surdud Group, a new lithostratigraphic unit of Jurassic age in the Yemen Arab Republic, Journal of King Saud University, Science 2, 125-143.

Geukense, F., 1966. Geology of the Arabian Peninsula (Yemen). United States Geological Survey Professional Paper 560-B, 1-23.

Glaessner, M.F., 1945. Principles of micropaleontology. Melbourne University Press, 1-296. 
Gordon, W.A., 1970. Biostratigraphy of Jurassic foraminifera: Geological Society of America Bulletin 181, 1689-1704.

Grigelis, A. \& Ascoli, P., 1995. Middle Jurassic - Early Cretaceous foraminiferal zonation and paleoecology of offshore Eastern Canada and the East European Platform. Geological Survey of Canada. - Open File No. 3099, 16 pp.

Grigelis, A. \& Norling, E., 1999. Jurassic geology and foraminiferal faunas in the NW Part of the East European Platform: a Lithuanian-Swedish geotraverse study. Sveriges Geologiska Undersökning (SGU). Series Ca, Research Papers 89, 101 pp.

Hassan, M.Y., Hassanein, A.M. \& Sharawy, Z.M., 1978. Jurassic stratigraphy of Mamura well, Western Desert, Egypt. Proceedings Academy of Science 31, 47-57.

Hewaidy, A.G.A. \& Al-Saad, H.A., 2000. Foraminiferal biostratigraphy of the Lower - Middle Jurassic sequences in Eastern Arabia. GeoResearch Forum 6, 95-104.

Howarth, M.K. \& Morris, N.J., 1998. The Jurassic and Lower Cretaceous of Wadi Hajar, southern Yemen. Bulletin of the Natural History Museum, Geology Series, London 54-1, 1-32.

Kalantari, A., 1969., Foraminifera from the Middle Jurassic-Cretaceous successions of Koppet-Dagh region (NE Iran). National Iranian Oil Company, Geological Laboratories Publications 3, 298 pp.

Kalia, P. \& Chowdhury, S., 1983. Faraminiferal biostratigraphy, and environment of the Callovian sequence, Rajastan, Northwestern India. Micropaleontology 29, 223-254.

Kuznetsova, K.I., Grigelis, A., Adjamian, J., Jarmakani, E. \& Hallaq, L., 1996. Zonal Stratigraphy and Foraminifera of the Tethyan Jurassic (Eastern Mediterranean). Gordon \& Breach Science Publishers, Amsterdam, 256 pp.

Lamare, P., 1923. Note prelimiare sur La structure de La region du Yemen. Société géologique de France 23, 19-61.

Lamare, P., Basse, E., Dreyfus, M., Lacroix, A. \& Tilhard De Chardin, P., 1930. Etudes geologiques en Ethiopie, Somalie et Arabie Meriodionale. Mémoires de la Société géologique de France 6, 83 pp.
Natland, M.L., 1933. The temperature and depth distribution of some recent and fossil foraminifera in the southern California region. Bulletin of the Scripps Institution of Oceanography, La Jolla, California, Technical series 3, 225-230.

Norton, R.D., 1930. Ecologic relations of some foraminifera: Bulletin of the Scripps Institution of Oceanography, La Jolla, California, Technical series 2, 331-388.

Redmond, C.D., 1964a. The Foraminiferal family Pfenderinidae in the Jurassic of Saudi Arabia. Micropaleontology 10, 251-263.

Redmond, C.D., 1964b. Lituolid foraminifera from the Jurassic and Cretaceous of Saudi Arabia. Micropaleontology 10, 405-414.

Sarfi, M. \& Yazdi-Moghadam, M., 2016. Stratigraphy of the Upper Jurassic shallow marine carbonates of the Moghan area (NW Iran), with paleobiogeography implication on Alveosepta jaccardi (Schrodt, 1894). Geopersia 6, 187-196.

Simmons, M. \& Al-Thour, K., 1994. Micropaleontological and biozonation of the Amran Series (Jurassic) in the Sana'a region, Yemen Republic. [In:] M. Simmons (Ed.): Micropaleontology and hydrocarbon exploration in the Middle East. British Micropaleontological Society Publication Series, Chapman \& Hall, London, 43-80.

Souaya, F.J., 1976. Foraminifera of Sun-Gulf-Global Linckens Island Well p-46, Arctic Archipelago, Canada. Micropaleontology 22, 249-306.

Wall, J.H., 1960. Jurassic microfauna from Saskatchewan. Saskatchewan Department of Mineral Resources Report 53, 229 pp.

Williams, G.L., Ascoli, P., Barss, M.S., Bujak, J.P., Davis, E.H., Fensome, R.A. \& Williamson, M.A., 1990. Biostratigraphy and related studies. [In:] M.J. Keen \& G.L Williams (Eds): Geology of the continental margin of eastern Canada. Geology of Canada. Geological Survey of Canada 2, 87-137.

Manuscript received: 12 October 2016 Revision accepted: 24 April 2017 